\title{
ROYAL WAQF IN PERAK: A LEGAL AND HISTORICAL ANALYSIS
}

\author{
Salehuddin Md. Dahlan* \\ Nor Asiah binti Mohamad** \\ Nuarrual Hilal Md. Dahlan***
}

\begin{abstract}
This paper analyses the legal and historical development of waqf made by Sultan Idris Murshidul' adzam Shah in Perak (1849 to 1916). There are many untraceable, lost, and perished waqfs in Malaysia. However, Sultan Idris's waqf is an exception which still exists since its establishment in 1917. As such, this research intends to explore its sustainability factors. The research methodology used is the doctrinal and non-doctrinal research methods. The doctrinal method is used to analyse the enactments, government gazettes, audit reports, journal articles, and history books. Meanwhile, the non-doctrinal legal method, namely semi-structured interview, clarifies findings and information gathered from various documents. The research is essential as there is a lack of comprehensive research done on waqf made by the Sultans or the Head of State in Malaysia. The researcher finds that the waqf was an established under written legal instrument; the waqf by Sultan Idris was made based on the English law of trust, but the spirit and principles of waqf to permanently benefit the beneficiaries remain intact; the appointment of the Sultan's descendants as the trustees alongside a committee proved to be crucial for the sustainability of the waqf; and there was check and balance process through legal provision. This research provides a clearer picture of waqf practice before the establishment of Perak's State Islamic Religious Council and evidenced the Sultan's contribution towards developing and protecting Islam.
\end{abstract}

* Ph.D. candidate at Ahmad Ibrahim Kulliyyah of Laws, International Islamic University Malaysia. Email: salehuddin78@gmail.com.

** Associate Professor at Ahmad Ibrahim Kulliyyah of Laws, International Islamic University Malaysia. Email: nasiahm@iium.edu.my.

*** Professor of Law at Universiti Utara Malaysia. Email: nuarrualhilal@uum.edu.my. 
Keywords: $\quad W a q f$, royal waqf, Perak, sustainability, Sultan Idris Murshidul' adzam Shah.

\title{
WAKAF DIRAJA PERAK: SUATU ANALISA UNDANG- UNDANG DAN SEJARAH
}

\begin{abstract}
ABSTRAK
Makalah ini menganalisa perkembangan undang-undang dan sejarah wakaf milik Sultan Idris Murshidul 'adzam Shah dari negeri Perak (1849 hingga 1916). Terdapat banyak harta wakaf yang tidak dapat dikesan, hilang dan telah musnah di Malaysia. Namun wakaf Sultan Idris terkecuali kerana masih lagi wujud sejak penubuhannya pada tahun 1917. Justeru kajian ini bertujuan untuk meneroka faktor kelestarian wakaf ini. Kaedah kajian yang digunapakai adalah kaedah doktrinal dan bukan doktrinal. Kaedah doktrinal melibatkan analisa enakmen, warta kerajaan, laporan audit, artikel jurnal dan buku sejarah. Manakala kaedah undang-undang bukan doktrinal yang digunakan adalah temubual separa struktur untuk menjelaskan penemuan serta maklumat yang diperolehi daripada pelbagai dokumen. Kajian ini penting bagi mengisi kekurangan kajian komprehensif tentang wakaf Sultan atau ketua negara Malaysia. Penyelidik mendapati bahawa wakaf adalah ditubuhkan berdasarkan undang-undang bertulis; wakaf Sultan Idris menggunapakai prinsip 300amanah Inggeris namun seiring roh dan prinsip wakaf yang memastikan manfaat kekal kepada benefisiari; perlantikan waris Sultan sebagai pemegang amanah bersama komiti menunjukkan kepentingan kelestarian wakaf; dan kewujudan sistem semak dan imbang melalui peruntukan undang-undang. Kajian ini memberi gambaran yang lebih jelas tentang kaedah wakaf yang digunapakai sebelum wujudnya Majlis Agama Islam Negeri Perak, yang menjadi bukti kepada sumbangan Sultan dalam pembangunan dan perlindungan ajaran agama Islam.
\end{abstract}

Kata kunci: Wakaf, wakaf diraja, Perak, kelestarian, Sultan Idris Murshidul' adzam Shah. 


\section{INTRODUCTION}

Waqf is primarily a religious endowment, partly as revenue-generating assets, regulated by Islamic Law. ${ }^{1}$ The authority for waqf is through hadiths explicitly ${ }^{2}$ and Quranic verses impliedly. ${ }^{3}$ Since the migration of Prophet Muhammad (PBUH) to Madinah, waqf has been part and parcel of Islamic practice. ${ }^{4}$ It has vastly contributed economically and socially to both the Islamic and non-Islamic countries. ${ }^{5}$ Some of the influence waqf could be seen in the redistribution of wealth, education, and health. ${ }^{6}$

In Malaysia, before the millennium waqf contributions were traceable primarily to religious purposes, such as mosques, religious schools, and cemeteries. Some of them are lost and perished without a trace. ${ }^{7}$ They include the great mosque of the Malacca Sultanate, the religious institution at Lubuk Pelang, Jerantut, and the mosque established by the first Sultan of Johor, i.e. Sultan Allaudin Riayat Shah in Johor Lama. Although there is an increased interest among the society to donate their properties for waqf, the property would likely take a long time to be developed for the benefit of society. ${ }^{8}$ It defeats

Abdul Hamid Mar Iman and Mohammad Tahir Sabit Mohammad, Waqf Property: Concept, Management, Development and Financing (Johor Bahru; Penerbit UTM Press, 2014); 3.

2 Muhammad Muhsin Khan, The Translation of the Meanings of Sahih AlBukhari, Volume 4, (Madina: Darussalam Publishers and Distributors, 1997), Hadith 2764: 33.

3 Ali Imran: 92.

4 Masoud Ahmad, "Role of Waqf in Sustainable Economic Development and Poverty Alleviation: Bangladesh Perspective," Journal of Law 42 (2015): 2224-3259; 118.

5 MY Ali and F Khanom, "Understanding Cash Waqf: It's Role Toward Alleviating Poverty In Contemporary Context," no. 12 (2014): 43-64, http://ddms.usim.edu.my/handle/123456789/9911.

6 Murat Cizakca, "The Waqf, Its Basic Operational Structure, Development and Contribution," in Kuala Lumpur: Roundtable Discussion on Development of Waqf Properties in Malaysia, INCEIF-IDB/IRTI Workshop (Kuala Lumpur, 2014), 1-16.

7 Syed Khalid Rashid, "Certain Legal and Administrative Measures for The Revival and Better Management of Awqf," Islamic Economic Studies 19, no. 1 (2011): 1-40.

8 Anwar Allah Pitchay and Mohamad I'sa Abd Jalil, "The Constraints Of Malaysian Mutawalli In Developing Idle Waqf Lands," The Muktamar 
the call from a hadith that waqf (sadaqa jariah) should continuously benefit others for the founder to get the reward from Allah (swt). ${ }^{9}$ Many factors contributed to this situation, such as fund mismanagement, ${ }^{10}$ financial constraints, ${ }^{11}$ human resources limitation, ${ }^{12}$ database insufficiency, ${ }^{13}$ and legal impediments. ${ }^{14}$

However, after a close study of earlier literature, it is found that there is a particular type of waqf that stood the test of time and still brings benefits until today. This type of waqf is a waqf established by royalties. One of which is Sultan Idris's waqf, situated in Kuala Kangsar, Perak.

Previously, Siti Mashitoh, Magda, and Nor Ardina have discussed Sultan Idris's waqf, albeit in a different context. While Siti Mashitoh described the overall waqf briefly, ${ }^{15}$ Magda $^{16}$ and Nor Ardina ${ }^{17}$ focused on one part of the waqf, namely Madrasah Idrisiah.

Waqf Iqlimi III 2016 (IQLIMI2016) 2016, no. October (2016): 13-14, https://doi.org/10.13140/RG.2.2.11520.84483.

9 AI-Imam Muslim, English Translation of Sahih Muslim, ed. Hafiz Abu Tahir Zubair Ali Za'i, Volume 4 (Riyadh: Darussalam, 2007). Hadith 4223: 371.

10 Rabiatul Hasanah Mahmood et al., "Kawalan Dalaman Tadbir Urus Wakaf Di Malaysia," Asian Journal of Accounting and Governance 8, no. Special Issue (2017): 49-58, https://doi.org/10.17576/ajag-2017-08si-05.

11 Zariana Sahari and Muhammad Ridhwan Ab. Aziz, "An Exploratory Study on Instruments of Waqf Financing," The Journal of Muamalat and Islamic Finance Research 10, no. 1 (2013): 91-106, https://doi.org/10.12816/0008160.

12 Nurul Azma et al., "Exploring the Factors of Organization Structure To Improve Waqf Management in Malaysia," Ijib 2, no. 2 (2017): 79-88.

13 Syed Khalid Rashid and Syed Khalid Rashid, "Measures For The Better Management of Awqaf," IIUM Law Journal 20, no. 1 (2012): 103-37, https://doi.org/10.31436/iiumlj.v20i1.77.

14 Syed Abdul Kader Sharifah Zubaidah et al., "Current Legal Issues Concerning Awqaf In Malaysia," University Utara Malaysia Repository, 2006, 29-37, https://doi.org/10.1017/CBO9781107415324.004.

15 Siti Mashitoh Mahamood, 34-35.

16 Magda, 82-83.

17 Nor Ardina binti Abdul Kadir, "Madrasah Idrisiah Bukit Chandan Kuala Kangsar Perak: Sejarah dan Sumbangannya Terhadap Pendidikan Islam dari Tahun 1985-1999," (Masters Dissertation, University Malaya, 2010); 73. 
However, further details on the legal and historical analysis of the waqf were not discussed. ${ }^{18}$

As such, the research objective of this writing paper is to find out the sustainability factors that led to its survival. To reach the research objective, this writing examines the legal and historical perspective of the royal waqf of Sultan Idris in Perak which is one of the oldest royal waqf in Malaysia.

\section{THE CONCEPT OF WAQF IN ISLAM}

\section{i. Definition}

According to Monzer Kahf, waqf in Arabic means to hold, confinement or prohibition. ${ }^{19}$ On the other hand, the word waqf in contextual meaning refers to the holding of specific properties and preserves them for the confined benefit of particular philanthropy and the prohibition of any use or disposition outside that specific objective. Other words that connote the same meaning with waqf are habs, ${ }^{20}$ tasbil, tahbis, or tahrim. ${ }^{21}$

\section{ii. Legitimacy of $\boldsymbol{W a q f}$}

Waqf legitimacy is mainly derived from hadiths and several implied Quranic verses. The authoritative hadith on waqf is the one reported by Ibnu Omar (d. 71 A.H.) that; Umar acquired a piece of land at Khaybar. He came to Allah's Prophet (peace be upon him) and sought his advice concerning it. He said: Allah's Messenger, I have acquired a piece of land in Khaybar, I have never acquired property more valuable for me than this, and so what do you command me to do it? Thereupon he (Allah's

\footnotetext{
18 Ibid.

19 Monzer Kahf and Siti Mashitoh Mahamood, Essential Readings in Contemporary Waqf Issues (Kuala Lumpur; CERT Publications, 2011); 45.

20 Ibnu Manzur, Abu al-Fadl Jamal al-Din Muhammad b. Mukarram, Lisanul Arab, vol.3 (Beirut: Dar Ehia Al-Tourath Al-Arabi, 1999); 19.

21 Abdul Hamid Mar Iman and Mohammad Tahir Sabit Mohammad, Waqf Property: Concept, Management, Development and Financing (Johor Bahru: Penerbit UTM Press, 2014); 12.
} 
Prophet) said: If you like, you may keep the corpus intact and give its produce as sadaqa. So, Umar gave it sadaqa, declaring that property must not be sold, inherited, or given away as a gift. Umar devoted the property to the poor, nearest kin, freeing the slaves, and other pious acts. There is no sin for one who administers it if he eats something from it reasonably or feeds his friends and does not hoard up goods (for himself). He (the narrator) said: I narrated this hadith to Muhammad, but as I reached the words "without hoarding (for himself) out of it," he (Muhammad) said: "without storing the property to become rich." Ibn Aun said: He who read this book (on waqf) informed me that in it (the words are) "without storing the property to become rich." 22

This hadith mentioned several essential principles of waqf such as follow; (1) cessation of ownership through Muhammad's order that the land could neither be sold, given away, or inherited; (2) beneficiaries of waqf are the poor, nearest kin, and so on; (3) the right to waqf's yield by its administer; (4) type of property endowed should have a permanency quality.

\section{iii. Types of $W a q f$}

Initially, there was no classification of waqf among jurists. ${ }^{23}$ However, currently, waqf can be divided into two major categories, i.e., waqf am and waqf khass. Waqf am is a waqf for general or public purposes. Examples of waqf am are hospitals, public libraries, and the public well. On the other hand, waqf khass means a dedication in perpetuity of an asset's capital and income, recognised by Islamic law, for religious, charitable, or educational purposes, dedicated for a specific purpose or for a particular individual, including the founder's family or his descendants as prescribed in the waqf deed. It includes private waqf and family waqf.

22 Imam Muslim, Sahih Muslim, translated from Arabic by Abdul Hamid Siddiqi (New Delhi: Kitab Bhavan, 2000); 1047.

23 Muhammad Kamal al-Din as cited in Mohd Afandi Mat Rani et. al, Transformasi Wakaf di Malaysia: Isu dan Cabaran (Shah Alam: IKaZ, 2014); 7. 
A sub-type of waqf khass is royal waqf. In Malaysia, evidence of the royal waqf is traceable in a few states, such as the Waqf of Kolej Islam Malaya in Selangor, Waqf Chenderong in Terengganu, and Wakaf Raja Palawan in Kelantan. Sultan Idris waqf in Perak is proof that such waqf still exists and benefits the people.

\section{iv. Pillars of $w a q f$}

There are four pillars of waqf under Shafii, Hanbali, and Maliki schools, namely; (1) the sighah (declaration), (2) the waqif (founder), (3) the mawquf 'alaih (beneficiary), and (4) the mawquf (endowed property). As for the Hanafi, however, there is only one pillar for waqf, namely, the sighah (declaration). ${ }^{24}$

\section{ROYAL WAQF (AWQAF AS-SALATIN)}

According to Magda, Awqaf as-Salatin (royal waqf) is created by ministers, princes, and their wives. ${ }^{25}$ However, the definition could be improvised by including waqf by the Rulers, namely the Sultans and the Rajas. Examples of royal waqf are Caliph Abu Bakr, who endowed his house to his children; Caliph Umar al-Khattab who endowed his land at Thamgh to his children; or Caliph Ali Abu Talib who endowed his land at Yanbu. ${ }^{26}$ She also mentioned the vast waqf created by many Ottoman Sultans and rulers for schools, hospitals, mosques, agricultural land, and industries ${ }^{27}$.

In India, the earliest mosque built was by the grace of an Indian king known as Cheraman Perumal in 621 AD. The mosque is called Cheraman Juma Mosque, situated at Methala, Kodungallur Taluk, Thrissur district in Kerala. ${ }^{28}$ On the other hand, Sultan Muizuddin Sam

24 Abdul Hamid Mar Iman and Mohamad Tahir Sabit Mohammad, Waqf Property: Concept, Management, Development and Financing (Johor Bahru; Penerbit UTM Press, 2014); 14.

25 Magda; 17.

26 Ibid, 14.

27 Ibid, 16.

28 Nathan Katz, "The Judaisms of Kaifeng and Cochin: Parallel and Divergent Styles of Religious Acculturation," Numen 42, no. 2 (1995): 122, https://doi.org/10.1163/1568527952598594. See also Richard W. 
dedicated two villages to Jama Masjid of Multan during his reign in 1185-1195 AD and gave its administration to a Sahik-al-Islam. ${ }^{29}$

Similarly, Salahuddin al-Ayyubi, the Sultan of Egypt and Syria alienated a large land scale to support religious foundations for various philanthropic services. ${ }^{30}$ Meanwhile, the Mamluk Sultans donated water supply, hospitals, and public kitchens as waqf. ${ }^{31}$ During the Ottoman caliphates, Sultan Murad III made an endowment called dashishasughra, and Sultan Mehmet IV's wife alienated an agricultural land in Egypt for the Holy Cities. ${ }^{32}$

Marinid sultans were also known to donate mosques, zawiyas, hospitals, and madrasas as waqf between 1321 and 1356 AD in Morocco $^{33}$. To pay the salaries of teachers and students' expenses of the madrasas, the sultans created revenue-producing properties such as stores for commerce and crafts, houses, apartments, stables, public baths, mills, orchards, public ovens, inns, halls, factories for weaving and soap making and arable land ${ }^{34}$.

During the Abbasid era in Andalusia, Caliph al-Hakam II set up a foundation with rents from the shops in the Cordova market to pay the foundation teachers' salaries. ${ }^{35} \mathrm{He}$ also used the revenues from rural properties inherited from his father to enlarge mosques in Cordova.

Franke and Barbara H. Chasin, Power to the Malayalee People, Economic and Political Weekly Vol. 32, No. 48 (29th November - 5th December 1997), 3062.

29 Magda; 170.

30 Doris Behens-Abouseif, "Wakf in the Arab Lands" in The Encyclopaedia of Islam edited by P.J. Bearman, TH. Bianquis, C.E. Bosworth, E. Van Donzel and W.P. Heinrichs, Vol. XI (Leiden; Brill, 2002); 64.

31 Ibid.

32 Ibid, 66.

33 D.S. Powers, "Wakf in North Africa" in The Encyclopaedia of Islam edited by P.J. Bearman, TH. Bianquis, C.E. Bosworth, E. Van Donzel and W.P. Heinrichs, Vol. XI (Leiden; Brill, 2002); 69.

34 Ibid.

35 A. Carmona, "Wakf in Muslim Spain" in The Encyclopaedia of Islam edited by P.J. Bearman, TH. Bianquis, C.E. Bosworth, E. Van Donzel and W.P. Heinrichs Vol. XI (Leiden; Brill, 2002); 76. 
In Fars, the wife of the province's Ruler, Zahida Khatun, spent all the money, treasure, and jewels to purchase large villages and make them waqf for the madrasah she built in Shiraz. ${ }^{36}$

The literature above shows that waqf practices were common among Muslim rulers and leaders in the past.

\section{COMPARISON BETWEEN ROYAL WAQF AND GOVERNMENT WAQF (WAQF IRSOD)}

The main difference between royal waqf and government waqf is the profile of the waqif (founder) as well as the source of the mawquf. Under the pillars of waqf, the mawquf must be a property that belongs to the waqif and is not subject to any condition or restriction. For the royal waqf, the waqif is the Sultan or his ministers, princes, and wives.

On the other hand, government waqf (waqf irsod) is made by the 'Baitulmal' or local authority to construct essential infrastructures for Muslims' benefit. ${ }^{37}$ It may refer to any waqf initiated by the government or any authority using government funds in the current context. Thus, if a sultan declares a reserved area as waqf, it falls under waqf irsod since the mawquf is not a property belonging to the sultan. While the royal waqf may be initiated by the sultan or his family, the source of the mawquf must be a property or asset that belongs to the sultan or that of royal properties.

\section{LEGAL ANALYSIS OF SULTAN IDRIS'S WAQF}

In order to analyse the legal aspect of Sultan Idris's waqf, we will start by analysing the legal background of Perak during Sultan Idris's lifetime i.e.,, from 1849 to 1916.

36 Ann K.S. Lambton, "Wakf in Persia", in The Encyclopaedia of Islam edited by P.J. Bearman, TH. Bianquis, C.E. Bosworth, E. Van Donzel and W.P. Heinrichs, Vol. XI (Leiden; Brill, 2002); 83.

37 Bhari, Azri, Mohd Afandi Mat Rani, A. Rahman, Nor Azira Mohd Radzi, L. Abdullah, Muhammad Ikhlas Rosele, Baharuddin Sayin and Muhammad Hamizan Bin Ab Hamid. "The Important Development of Executing of 'Waqf Irsod' in Contemporary Malaysia." Advanced Science Letters 22 (2016): 2191-2193. 


\section{i. Administration of Islam During the British Colonisation in the Federated Malay States}

During British colonisation, it is well acknowledged that the British practised the separation of law relating to religious matters and public matters. The Pangkor Treaty is essential evidence as it marked the beginning of the power transfer from Sultan Perak to the British. ${ }^{38}$ The treaty involved Sir Andrew Clarke, Governor, Commander-inChief, and Vice-Admiral of the Straits Settlements, and Raja Abdullah, the Sultan of Perak, signed on $20^{\text {th }}$ January 1874. Clause 6 of the Treaty stated that "... Sultan receives and provides a suitable residence for a British Officer to be called Resident, who shall be accredited to his Court, and whose advice must be asked and acted upon on all questions other than those touching Malay Religion and Custom." (emphasis included)

Consequently, this treaty legally separated the Islamic administration from the State government's purview and put it under the Sultan's power. As such, the Sultan became the head of the religion of Islam. However, actual administration was done by the kadhis and the assistant kadhis, especially in marriage, divorce, and other matters regulated in the Mahommedan Law. ${ }^{39}$ This arrangement has resulted in the matters on waqf to be assigned under kadhi or the mufti. In 1875, the Sultan's power had been decreased further with the formation of the State Council, which assisted the British Resident in all government business matters. ${ }^{40}$

In July 1895, four States, including Perak, agreed to constitute their states as a federation to be administered under the British Government's advice through the Treaty of Federation 1895. Consequently, this treaty made the four states Perak, Pahang, Selangor, and Negeri Sembilan as the Federated Malay States. ${ }^{41}$ Under this treaty,

38 Allen, J. De V., A. J. Stockwell, and L. R. Wright. A Collection of Treaties and Other Documents Affecting the States of Malaysia, 1761-1963. No ed. Vol. I. (London: Oceana Publications, 1981): 390-392.

39 Awee binti Ujang v. Ibrahim bin Jamal (1916) FMS 274.

40 Izdihar Baharin and Rizal Yaakop Azrai Abdullah, "The Transformation of Perak's Political and Economic Structure in the British Colonial Period in Malaya (1874-1957)," Jebat: Malaysian Journal of History, Politics and Strategic Studies 39, no. December (2012): 63-72.

41 H. Conway Belfield, Handbook of The Federated Malay States (London: Edward Stanford, 1902). 
the states agreed to accept a British officer called Resident-General as an agent of the British Government under Governor of the Straits Settlements' instruction. It was agreed that the rulers have to follow the Resident-General's advice in all administration matters except the Islamic religion. Consequently, these two treaties "...provided that the advice of the British administrators should be followed and by such advice, courts have been established British judges were appointed, and a British administration was established." 42

The policy of separation of laws was further defined by section 140 of The Probate and Administration Enactment 1904 (Cap. 8), where it says, "Nothing contained in this Enactment shall affect any rules of Mohammedan Law as varied by the local custom in respect of the distribution of the balance of the estate of a deceased person after the debts have been satisfied." This situation was starkly different before the colonisation period, where the Court agreed that the only law applicable to the Malays was Islamic law modified by local customs ${ }^{43}$.

However, this policy was continued in further treaties and proclamations, namely the Malayan Union in 1946, the Federation of Malay States in 1948, the Federation of Malaya in 1957, and the Federation of Malaysia in 1963. For example, under the Malayan Union White Paper, it was stated that:

8. In each State, side by side with the State Councils, there should be established advisory Malay Councils to the Sultans, which should be presided over by the Sultan and whose members, subject to the Governor's approval, should be appointed by the Sultan. The main functions of these Advisory Malay Councils would be in relation to matters affecting Mohammedan religion, but they would also advise the Sultan on other matters at the request of the Resident Commissioner and with the approval of the Governor. On matters of Mohammedan religion (with the exception of anything connected with the collection of taxes or tithes, which must be left strictly within the control of the Central Legislature' or the State Councils), it is proposed that the Sultans should have powers of legislating in their individual States. ${ }^{44}$

42 Shaikh Abdul Latif, Halima and Janiah v. Shaikh Elias Bux (1915) FMS Vol 1, 214.

43 Ibid.

44 Great Britain. Colonial Office. Malaya., Malayan Union and Singapore: Statement of Policy on Future Constitution (London : H.M.S.O., 1946).:4. 
This policy has made the sultans rely on the Malay councils and British officers in administering the State. The effect of this arrangement includes the position of waqf which was no longer administered by the kadhi but by the British indirectly and treated as trust according to the English laws. As evidence, Sultan Idris's waqfs were enacted under the Sultan Idris Religious and Charitable Trust Enactment 1917 (Pk. 3 of 1917) and the Sultan Idris Estate Enactment 1917 (Pk. 2 of 1917).

\section{ii. British's Treatment Towards Waqf in the Federated Malay States (FMS)}

As waqf is part and parcel of Islamic law, the British's treatment towards waqf in the Federated Malay States can be analysed through three rubrics: namely law, cases, and administration.

\section{a. Laws}

At a first glance, there were no specific waqf laws during the British occupation in the Federated Malay States. However, subsequently, several laws were established to directly or indirectly regulate the waqf. ${ }^{45}$ Some of the relevant laws on waqf enacted in the Federated Malay States from 1877 to 1920 were the Muhammadan Cemetery Reserve 1904 (Sel.8 of 1904), the Sultan Idris Religious and Charitable Trust Enactment 1917 (Pk. 3 of 1917), and the Sultan Idris Estate Enactment 1917 (Pk. 2 of 1917). The Muhammad Cemetery Reserve 1904 (Sel.8 of 1904) is considered as a waqf due to its perpetuity nature and the founders' intention.

Further analysis of the Sultan Idris Religious and Charitable Trust Enactment 1917 (Pk. 3 of 1917) and the Sultan Idris Estate Enactment 1917 (Pk. 2 of 1917) found a similarity to the Islamic law waqf. As already mentioned, under Islamic law of waqf, there are four pillars of waqf, namely; (1) the sighah (declaration), (2) waqif

45 Nuarrual Hilal bin Md. Dahlan and Abdul Rani Kamarudin, "Wakaf in Malaysia: Its Legal Evolution and Development," Shariah Law Report 1 (2006): 81-103. See also Sharifah Zubaidah Syed Abdul Kader and Nuarrual Hilal Md. Dahlan, Current Legal Issues Concerning Awqaf in Malaysia in Syed Khalid Rashid, ed., Waqf Laws and Management (Gombak; IIUM Press, 2017), 170 
(founder), (3) the mawquf 'alaih (beneficiary), and (4) mawquf (endowed property). Comparatively, under the two enactments, their establishment was similar to the sighah (declaration). Meanwhile, the waqif is Sultan Idris, the mawquf 'alaih for both the enactments were the family of Sultan Idris and the public, and lastly, the mawquf were the property of Sultan Idris as mentioned in the enactments.

\section{b. Case Law}

No specific waqf case was reported in the Federated Malay States, including Perak, from 1895 to 1940 . However, waqf-related cases were reported in the Straits Settlements instead. One of the early waqf cases is Shaikh Lebby v. Fateemah (1872) 1 Kyshe, 324, where Justice Hackett held that the land donated as family waqf through a letter of deed is not considered as a charity under English law. The basis of this judgment is that a family waqf lacks a public benefit element, and no trustee was appointed. The case started when the plaintiff wanted to eject the defendant from a piece of land, but the defendant opposed the suit relying on a deed claiming the lands were set aside as waqf for the donor's family. Instead, the judge believed that according to the Mohammedan law, the plaintiff should give up his request and act as a conscientious man.

The influence of English law on waqf can also be seen in the case of Ashabee \& Ors. v. Mahomed Hashim Anors (1887) IV Kyshe, 212 Justice Sheriff held that the waqf for children and descendants was void due to its perpetuity in nature. In this case, a bequest of $\$ 400$ for wife maintenance and kenduris (feast) was made without explicitly mentioning the exact portion for the maintenance and kenduris was considered void due to its uncertainty and perpetuity in nature. Instead, the plaintiff wanted to sell the land on the void bequest in this case as the testator died intestate. Similar judgment based on the same issue was also discussed in Ong Cheng Neo v. Yeap Cheah Neo(1872) 1 Kyshe 326.

The interference of the English judges continued and reflected in other decisions, for example, a conditional gift was considered a void gift. In Kader Bee \& Anor v. Kader Mustan (1878) 1 Kyshe, 432, Justice Wood held that a gift with a restraining clause was void due to its uncertainty status and application of the rule against perpetuity. In this case, Kader Saibo died with a will, leaving a piece of land to a 
trustee. The trust was for 60 years with a condition prohibiting the sale of the land for a period beyond 60 years. As such, his children and nextof-kin brought a suit to challenge the will against Kader Mustan, who was the will's executor and trustee. The gift consisted of three lots of lands with income, and the plaintiffs were entrusted with full power to transact the lands and gain income from it.

In Mahomed Ghouse v. Hajee Mohamad Saibo \& Anor (1885) IV Kyshe, 101, Justice Wood held that gift of lands to children was not void, but a restriction on alienating the lands is void. This is because the purported restriction in land alienation made was contrary to the rule against perpetuity. The fact of the case showed that the plaintiff, who was one of the testator's children, wanted to declare the whole clause of gift to be void. The defendant, who was the executor of the will, disagreed with the proposition. The fact shows that in Ghouse's case, a waqf element or spirit exists in an act referred to as a gift with an emphasis of no alienation of the land whatsoever. This case is proof that the colonial did not recognise local practices, customs, or religion. Instead, they interpreted the act and the law based on their laws and understanding.

In another case, holding kenduris for testators was held void, as in Mustan Bee \& Ors. v. Shina Tomby \& Anor (1882) 1 Kyshe, 580. In this case, Justice Sindgreaves opined that kenduris (feast) for testator's benefit is void due to the restraint of alienation and contrary to rules against perpetuity. As such, the trust deed executed by the defendant was canceled, and the property was conveyed to the plaintiff. Initially, the plaintiff, the next-of-kin of the testator, wanted the property and urged the court to declare the will as void. The defendants, who were the will's executors, were against the suit, used the limitation bar as the ground to challenge the case, i.e., 12 years after the will. This case followed the judgment from Fatimah v. Logan (1871) 1 Kyshe, 621, where holding of kenduris to the testator was not in line with the rules against perpetuity and thus became a void will.

Last but not least, Justice Pellerau, in Mootyah Chetty v. Yacob in Re Nyai Hamzah(1890) IV Kyshe, 568, held that houses built on waqf land are personal chattels thus removable similar to growing crops on the ground. In this case, the plaintiff brought an action to recover Nyai Hamzah's judgment, who previously borrowed some plaintiff money. One of Nyai Hamzah's properties was waqf land, where the defendant built one of the houses. The house was unregistered under the Bills of 
Sales Ordinance, and there was no conveyance of freehold or leasehold of the land. This case's gist is similar to Letchman Chetty v. Hassan Kudus \& Anors (1890) 4 Kyshe, 675, where the court held that a brick house was built on a waqf land is considered a personal chattel.

In short, the gist of these cases is that the British colonials viewed waqf as similar to trust laws. The principles of trust laws gathered from these cases are; (i) it should bring benefit to the public; (ii) it must have appointed trustee; and (iii) it must not remain perpetual. In the case of Sultan Idris's waqfs, a mixture of trust laws and waqf laws were applied, namely, (i) it bring benefit to Sultan's family $^{46}$ and public; ${ }^{47}$ (ii) appointment of trustees, ${ }^{48}$ and (iii) perpetual. ${ }^{49}$

46 The Sultan Idris Estate Enactment, 1917 (Pk. 2 of 1917), The Second Schedule.

47 Sultan Idris Religious and Charitable Trust (Pk.3 of 1917), Preamble reads, "...And whereas, it is the desire of His Highness Sir Abdul Jalil Nasruddin Makhtaram Shah, Sultan of Perak, and other the heirs of His said late Highness that the said lands should be vested in Trustees empowered to duly administer the same and to devote the income arising therefrom to the religious and charitable purposes hereinafter specified."

48 The Sultan Idris Estate Enactment, 1917 (Pk. 2 of 1917), s 3(i) reads, "His Highness tha Sultan and the Resident, with the consent of the Chief Secretary to Government, may, by notification in the Gazette, appoint a fit and propert person to be "The Trustee of the Sultan Idris Estate," and the person so appointed shall perform the duties imposed on the Trustee by this Enactment. See also Sultan Idris Religious and Charitable Trust (Pk.3 of 1917), s2(i) reads, "His Highness the Sultan and the Resident, with the consent of the Chief Secretary, may from time to time by notification in the Gazette appoint, by name or office, fit and proper persons to be Trustess under this Enactment, either as original Trustees or additional Trustees or in substitution for Trustees dying or ceasing under the provisions of this Enactment to be Trustees, but so that not more than three persons shall be appointed to be at one and the same time Trustees under this Enactment."

49 The Sultan Idris Estate Enactment, 1917 (Pk. 2 of 1917) s 10 reads, "The Trustee shall not, without the written assent both of the Ruler of the State and of the Resident first obtained, sell, transfer, mortgage, charge or otherwise encumber any part of the lands vested in him nor, without such written assent as aforesaid, lease or otherwise dispose of any part of the said lands for any period exceeding three years. Every atempt to sell, transfer, mortgage, chare, encumber, lease or dispose of the said lands or 


\section{c. Administration}

The Sultan of Perak held power to administer Islamic matters, including waqf, during the British occupation in Perak. This practice had changed from the early history of the administration of Islam in the Malay states. During the pre-colonisation period, the sultan had the full authority and power to administer matters of custom and Islam. The concept of Islam was referred to as ritual and more inclusive, for example, how the land was distributed, distribution of taxes, and dispute resolution among people and others. Milner admitted that in 1878, the legal practice in Perak followed the Undang-Undang Melaka, which is a composite document and includes the Islamic law elements. ${ }^{50}$

During the British colonisation, many changes in the administration system have occurred, especially in the Straits Settlements. The impact could also be seen in Perak, where the British had appointed an adviser to the sultan and introduced a court system where they appointed the English or English-trained judges.$^{51}$ Although disputes on Islamic matters were supposed to be brought to the Kadhi, most cases were brought to the civil court, treating them as trust. Nevertheless, there was no waqf case brought to the civil court during the time of British colonisation in Perak.

All in all, it could be safely said that waqf was treated as a trust under the British colonisation in the Federated Malay States and Perak, especially. Now let us analyse two waqfs made by the Sultan of Perak. Interestingly both waqfs were established by the Sultan in Council after the death of Sultan Idris.

any part thereof in contravention of the providions of this section shall be null and void and of no effect."

50 A.C. Milner, "Islam and Malay Kingship," Journal of the Royal Asiatic Society of Great Britain and Ireland 1 (1981): 46-70.

51 Mohd Roslan Mohd Nor, Ahmad Termizi Abdullah, and Abdul Karim Ali, "From Undang-Undang Melaka to Federal Constitution: The Dynamics of Multicultural Malaysia," SpringerPlus 5, no. 1 (2016), https://doi.org/10.1186/s40064-016-3360-5. 6. 


\section{iii. The First Waqf (Family Waqf)}

The first waqf by Sultan Idris is a family waqf established through the Sultan Idris Estate Enactment 1917 Cap 208 (Pk. 2 of 1917). ${ }^{52}$ This Enactment governed Sultan Idris's hundred and ninety-seven (197) property titles in six different districts in Perak, namely Kuala Kangsar, Krian, Ipoh, Kampar, Kinta, and Kinta Batang Padang. The property titles were divided into three types: agricultural titles, town titles, and mining titles ${ }^{53}$, and were entrusted to a trustee appointed by the sultan of Perak and the resident with the chief secretary's consent. ${ }^{54}$ This arrangement was stated in the Enactment where it says, "The Trustee shall not, without the written assent, from both, the Ruler of the State and the Resident, sell, transfer, mortgage, charge, or otherwise encumber any part of the lands vested in him nor, without such written assent as aforesaid, lease or otherwise dispose of any part of the said lands for any period exceeding three years." 55

According to the Enactment, the trustee's primary task is distributing income from the said properties to Sultan Idris's six sons, ${ }^{56}$ seven daughters, ${ }^{57}$ and two wives ${ }^{58}$ according to Islamic law. ${ }^{59}$ Upon the death of the said persons, the income would be payable to such a person's heirs. ${ }^{60}$ The trustee was empowered to manage or supervise

52 Federated Malay States Government Gazette, 1917, Vol. IX, No. 10.

53 The Sultan Idris Estate 1917 (Pk. 2 of 1917), First Schedule,

54 The Sultan Idris Estate 1917 (Pk. 2 of 1917), s. 3(i).

55 The Sultan Idris Estate 1917 (Pk. 2 of 1917) s.10.

56 H.H. Abdul Jalil Makhtaram Shah ibni Almarhum Sultan Idris, Raja Alang Iskander Raja Bendahara ibni Almarhum Sultan Idris, Raja Harun Al Rashid ibni Almarhum Sultan Idris, Raja Abdul Rashid ibni Almarhum Sultan Idris, Raja Haji Shueib ibni Almarhum Sultan Idris and Raja Shahrudin ibni Almarhum Sultan Idris. See Sultan Idris Estate 1917 (Pk. 2 of 1917).

57 Raja Ngah Halimah binti Almarhum Sultan Idris, Raja Puteh Mahiah binti Almarhum Sultan Idris, Raja Puteh Kulsom binti Almarhum Sultan Idris, Raja Badariah binti Almarhum Sultan Idris, Raja Haliah binti Almarhum Sultan Idris, Raja Arbiah binti Almarhum Sultan Idris and Raja Patimah binti Almarhum Sultan Idris. See Sultan Idris Estate 1917 (Pk. 2 of 1917).

58 Raja Perempuan Aishah binti Almarhum Sultan Yusuf and Raja Permaisuri Uteh Mariah binti Haji Sleman. See Sultan Idris Estate 1917 (Pk. 2 of 1917).

59 The Sultan Idris Estate 1917 (Pk. 2 of 1917), s. 12 (i).

60 The Sultan Idris Estate 1917 (Pk. 2 of 1917), s. 12 (ii). 
the management of property according to the types of property. For example, in agricultural lands, he should cultivate the same manner previously cultivated and so forth ${ }^{61}$.

The trustee was also prohibited from selling, transferring, mortgage, charging, encumbering, leasing, or disposing of the said properties except with the state's ruler and the resident's written assent. ${ }^{62} \mathrm{He}$ was also responsible for paying all expenses related to the management of the properties. ${ }^{63}$ The first appointed trustee for this waqf was Arthur Noel Kenion of Ipoh, Perak, in 1917. ${ }^{64}$ As for the current trustee, no information is available.

\section{Development of Sultan Idris Estate}

The Sultan Idris Estate Enactment 1917 Cap 208 (Pk. 2 of 1917) was established as required by the Probate and Administration Enactment 1904, where Sultan Idris died intestate pending the final distribution of the estate. The Enactment took a cue from a similar case: The Datoh Panglima Kinta's Intestate Estate Enactment 1904 (Enactment No. 18 of 1904). Datoh Panglima Kinta Muhammad Yusof bin Datoh Lasam was one of the wealthiest men in Perak, who left behind four living wives, eight sons, and seven daughters. All the mentioned names in the Enactment received their portion according to Islamic law. Unlike Sultan Idris's estate, all estates under Datoh Panglima Kinta were converted into money and distributed to the rightful beneficiaries totaling nineteen persons leaving none left behind.

The Sultan Idris Estate Enactment 1917 Cap 208 (Pk. 2 of 1917) has undergone a couple of amendments throughout the years. The earliest amendment took place in 1937, which stipulated that the Sultan could no longer act independently. Instead, he would be advised by the

\footnotetext{
61 The Sultan Idris Estate 1917 (Pk. 2 of 1917), s. 7.

62 The Sultan Idris Estate 1917 (Pk. 2 of 1917), s 10.

63 The Sultan Idris Estate 1917 (Pk. 2 of 1917) s 7 (ii).

64 Supplement to the Federated Malay States Government Gazette, 1917.
} 
council beforehand. ${ }^{65}$ Similarly, the Ruler in Council may approve the usage of income from the trust. ${ }^{66}$

The following amendment was made in 1957 to limit the authority of the resident where he no longer had the authority to appoint trustees ${ }^{67}$ prevent the trustee from being sued, ${ }^{68}$ give the assent of any transaction, ${ }^{69}$ exhibit trust accounts ${ }^{70}$, or access to trust information, or give written direction. ${ }^{71}$ Instead, the power was given to the Chief Minister (Menteri Besar) due to the change of political scenario in the state, i.e., the independence of the Malay States in 1957.

The Enactment had its last amendment in 1959 when the consent from the Chief Secretary to the government was not required to revoke the trustee's appointment ${ }^{72}$ or to use the trust's income. ${ }^{73}$

\section{iv. The Second Waqf (Religious Waqf)}

The second Enactment is the Sultan Idris Religious and Charitable Trust Enactment 1917 Cap. 209 (Pk. 3 of 1917). The Enactment comprised of sixteen properties located in Kuala Kangsar to be donated as waqf to public beneficiaries. It was enacted after the death of Sultan Idris in 1916 by his son's wish, the subsequent Ruler, i.e., Sir Abdul

65 Federated Malay States Enactment (No. 18 of 1937). The affected provision is S.3(i), The Sultan Idris Estate 1917 (Pk. 2 of 1917).

66 Federated Malay States Enactment (No. 18 of 1937). The affected provision is S.11, The Sultan Idris Estate 1917 (Pk. 2 of 1917).

67 Federal Legal Notice No. 161 of 1957. The affected provision is S. 3, The Sultan Idris Estate 1917 (Pk. 2 of 1917).

68 Federal Legal Notice (No. 161 of 1957). The affected provision is S. 6, The Sultan Idris Estate 1917 (Pk. 2 of 1917).

69 Federal Legal Notice (No. 161 of 1957). The affected provision is S.10, The Sultan Idris Estate 1917 (Pk. 2 of 1917).

70 Federal Legal Notice (No. 161 of 1957). The affected provision is S.14 (i), The Sultan Idris Estate 1917 (Pk. 2 of 1917).

71 Federal Legal Notice (No. 161 of 1957). The affected provision is S.15, The Sultan Idris Estate 1917 (Pk. 2 of 1917).

72 Federal Legal Notice (No. 293 of 1959). The affected provision is S.3(ii), The Sultan Idris Estate 1917 (Pk. 2 of 1917).

73 Federal Legal Notice (No. 293 of 1959). The affected provision is S.11, The Sultan Idris Estate 1917 (Pk. 2 of 1917). 
Jalil Nasrudin Makhtaram Shah, the heirs of Sultan Idris Mersid-elAa'zam. ${ }^{74}$

This situation was due to Sultan's intestate death, and as such, the Enactment was essential to protect the perpetuity of the waqf properties. The Enactment had provisions prohibiting the disposal of the said properties. It was clearly stated that the properties could not be sold, transferred, mortgaged, charged, encumbered, leased, or disposed of without leave from the court. ${ }^{75}$ A closer look at the properties showed sixteen landed properties equivalent to seven grant properties, five town leases, and four certificates of titles. ${ }^{76}$ All these properties were in shophouses and were registered in Kangsar Land and District Office, Perak. ${ }^{77}$

Another essential element of waqf is the appointment of nazir, which is usually referred to as trustee under the English administration of trust property. Thus, under the Enactment, the trustees were appointed by the Sultan and the Resident with consent from the Chief Secretary of the government with not more than three persons. ${ }^{78}$ The earliest appointed trustees were Raja Alang Iskandar ibni Sultan Idris (Raja Bendahara), Jeragan Abdul Shukor (Datoh Stia Bijaya di-Raja), and Kuala Kangsar District Officer. ${ }^{79}$ Currently, the trustees are Raja Iskandar Dzulkarnain ibni Almarhum Sultan Idris A'fifullah Shah

74 Sultan Idris Religious and Charitable Trust (Pk 3 of 1917), Preamble. See also Correspondence from Kuala Kangsar District Officer to the Perak State Secretary, 3 April 1948, File No (3), IN KKLO/102/48, National Archive, Kuala Lumpur, Malaysia. and The Sultan Idris Religious and Charitable Trust Enactment 1917 (Pk 3 of 1917) s.11.

75 Sultan Idris Religious and Charitable Trust (Pk 3 of 1917), s 5.

76 Sultan Idris Religious and Charitable Trust (Pk 3 of 1917), The Schedule.

77 Correspondence from Kuala Kangsar District Officer to the Perak State Secretary, 3 April 1948, File No (3), IN KKLO/102/48, National Archive, Kuala Lumpur, Malaysia. See also The Sultan Idris Religious and Charitable Trust Enactment 1917 (Pk. 3 of 1917), s 11.

78 The Sultan Idris Religious and Charitable Trust Enactment 1917 (Pk. 3 of 1917), s 2 (i).

79 Federated Malay States Government Gazette, 1918. 
(Raja Muda of Perak) $^{80}$ and Zulhisham bin Ahmad Shukori (Kuala Kangsar District Officer). ${ }^{81}$

Interestingly, the Chairman of Trustees usually comes from Sultan Perak's family members, although no such condition is mentioned in the Enactment. ${ }^{82}$ This practice is similar to the family waqf concept under Islamic law. The trustees are responsible for administering and managing the lands in good order and collecting rents and profit. ${ }^{83}$ They can be discharged or removed by the court's order by reasons of any application, refusal, incapable, unfit, or misconduct ${ }^{84}$ They are also responsible for keeping accurate accounts of income and profits from the lands and submitting them to the Resident $^{85}$ (currently to State Secretary) and subject to a yearly audit ${ }^{86}$ (currently by Auditor General Department).

Besides having trustees from the royal family, other committee members are government officers attached with Kuala Kangsar Land Office, which is currently held by Mr. Abu Yaziz Abas, who acts as the secretary of the trust fund. ${ }^{87}$ Combining a trustee from the founder's family and government official seemed to protect the waqf's sustainability.

80 Abas, Abu Yaziz, Interview by author.Kuala Kangsar, June 17, 2019. , "Direktori Pegawai," Pejabat Daerah dan Tanah Kuala Kangsar, <https://ptg.perak.gov.my/portal/web/kuala-kangsar/direktori-pegawai> (accessed 20 $0^{\text {th }}$, September 2021).

82 Sultan Idris Religious and Charitable Trust (Pk.3 of 1917), s 2(i) reads, "His Highness the Sultan and the Resident, with the consent of the Chief Secretary, may from time to time by notification in the Gazette appoint, by name or office, fit and proper persons to be Trustees under this Enactment, either as original Trustees or additional Trustees or in substitutiion for Trustees dying or ceasing under the provisions of this Enactment to be Trustees, but so that not more than three persons shall be appointed to be at one and the same time Trustee under this Enactment." The Sultan Idris Religious and Charitable Trust Enactment 1917 (Pk. 3 of 1917) s 4.

84 The Sultan Idris Religious and Charitable Trust Enactment 1917 (Pk. 3 of 1917), s 9.

85 The Sultan Idris Religious and Charitable Trust Enactment 1917 (Pk. 3 of 1917), s.12 (i).

86 The Sultan Idris Religious and Charitable Trust Enactment 1917 (Pk. 3 of 1917), s.12 (ii).

87 Ibid, Abas, Abu Yaziz. 
On the other hand, beneficiaries of the trust properties are also well recorded. For example, income and profits from these properties would then be distributed to pay; (1) its rent and taxes; (2) maintenance of Rizwaniah mosque which include the purchase of carpets, lamp, and salary of mosque officials; (3) maintenance of Makam Rahmatullah including remuneration for Al-Quran readers, caretakers, weekly religious feasts and purchase of oil and other accessories; (4) maintenance of Madrasah Idrisiah including furniture, teachers' salaries, student allowances, and other incidental requirements. ${ }^{88}$ All this evidence is common in other royal waqf reports, especially the Ottoman rulers' practices. ${ }^{89}$

Another incidental requirement is funding a new academic programme combining academic subjects with religious subjects and the Arabic language in 1975 and remuneration for clerk and office helpers during the $1970 \mathrm{~s} .{ }^{90}$ If there is an income surplus after the said distribution, the trustees can invest or dispose to help other Islamic religious or charitable institutions' furtherance subject to the Court's approval $^{91}$.

In terms of tenants, currently, there are nineteen shop lots occupied by Chinese (seventeen lots), Malay (one lot), and one vacant burnt lot. The Chinese tenants operated businesses such as pharmacies, dobby, watches, pipes, plastic wares, gold, and telecommunication paraphernalia. $^{92}$

\section{a. Development of Sultan Idris Religious and Charitable Trust}

\section{Legal development}

The Sultan Idris Religious and Charitable Trust Enactment 1917 Cap. 209 (Pk. 3 of 1917). was amended at least six times. The first

88 The Sultan Idris Religious and Charitable Trust Enactment 1917 (Pk. 3 of 1917), s.7 (i) (a) to (d).

89 Nur Ainul Basyirah Alias, Shamsul Azhar Yahya and Ermy Azziaty Rosli, Islamic Civilization Through Waqf Institutions in Ottoman Empire Between $15^{\text {th }}$ Until $17^{\text {th }}$ Century, Jurnal Hadhari 12 (2) 2020, 193.

90 Noor, 99.

91 The Sultan Idris Religious and Charitable Trust Enactment 1917 (Pk. 3 of 1917), s 8.

92 Abas, Abu Yaziz, Interview by author.Kuala Kangsar, June 17, 2019. 
amendment was made on $4^{\text {th }}$ June 1918 due to an error on one of its land grants where the certificate of title number 1,148 was wrongly printed as number $1,145 .^{93}$

Occasionally, the trustee would alter the distribution of income derived from the trust. For instance, in 1918, the trustee obtained consent from the Chief Secretary of the Federated Malay States to balance a stamp duty amounting to $\$ 6,576$ to purchase tombstones for Almarhum Rahmatullah's grave, one of the beneficiaries of Sultan Idris Religious and Charitable Trust. ${ }^{94}$

Then in 1920, three repeals from section 7 of the said Enactment were made, namely; (1) repeal of a definite amount of contribution to Ridzwaniah Mosque in terms of purchase of mosque's equipment and official salaries; (2) repeal of a definite amount of remuneration and expenditure towards Makam Rahmatullah; and (3) repeal of a definite amount of purchase of furniture and salaries and allowances. As such, trustees could decide any amount, whichever they think fits. ${ }^{95}$

The following amendment was made in 1937 when "His Highness the Sultan" was changed to "The Ruler in Council." Then in 1939, the phrase "at a cost for such purchase not exceeding in all one thousand dollars" was deleted, giving the purchase to an unlimited cost. ${ }^{96}$ An amendment in 1957 saw the word 'Resident' was changed to Menteri Besar $^{97}$ due to a political scenario change, i.e., the

93 The Sultan Idris Religious and Charitable Trust Enactment 1917, Amendment Enactment, $1918 \quad$ (Enactment No. 3 of 1918), s 2.

94 File minute by Chief Secretary of Federated Malay States, 3.10.1918, H.C.O. No. CH: SEC: 1729/1918, 1957/0606283, Arkib Negara Malaysia, Kuala Lumpur, Malaysia.

95 The Sultan Idris Religious and Charitable Trust Enactment 1917, Amendment Enactment 1920 (Enactment No. 3 of 1920), s 2. See also Federated Malay States Government Gazette, 1920, Vol. XII, No. 22.

96 The Sultan Idris Religious and Charitable Trust (Amendment) Enactment 1939 (Enactment No. 6 of 1939), s 2. See also Federated Malay States Government Gazette, 1939, Vol. XXXI, No. 18. The affected section is s.7(i)(b), The Sultan Idris Religious and Charitable Trust Enactment 1917 (Pk. 3 of 1917).

97 Legal Notification No. 161 dated $4^{\text {th }}$ April 1957. Affected sections are S. 2 (i), S. 6 (i) and (ii), S.11 (i)(b) and (c), S.12 (i) and (ii), The Sultan Idris Religious and Charitable Trust Enactment 1917 (Pk. 3 of 1917) 
Independence of Malay States. Last but not least, in 1959, consent from Chief Secretary was not needed for the appointment of trustees. ${ }^{98}$

\section{Financial Development}

At present time, the Sultan Idris Religious and Charitable Fund sources of income are from the rental building (highest revenue), land rental, hibah, and fixed deposit interest (lowest revenue). For example, in 2015, the total income was MYR217,020 (USD52,464.67), from which MYR188,100 (USD45,473.25) came from the rental building, MYR8,600 (USD2,079) from land rental, MYR4,635 (USD1,120.51) from the fixed deposit, and MYR15,685 (USD3,791.86) from hibah. In 2015, total expenses were MYR211,373 (USD51,099.51), which include loan payment, land tax, electric and water, salary, and property maintenance. ${ }^{99}$. For comprehensive income and expense statements from the year 2002 to 2017, please refer to Table 1.

Table 1: Financial Performance for Sultan Idris Religious and Charitable Trust 2002-2017.

\begin{tabular}{|l|l|l|l|l|l|l|}
\hline \multirow{2}{*}{ Year } & \multicolumn{3}{|c|}{$\begin{array}{l}\text { Comprehensive Income Statement Ended } \\
\mathbf{3 1}^{\text {st }} \text { December Every Year (MYR mil) }\end{array}$} & \multicolumn{2}{l|}{$\begin{array}{l}\text { Financial Statement Ended in 31 } \\
\text { Every Year (MYR mil) }\end{array}$} \\
\cline { 2 - 7 } & Income & Expense & Surplus/(Deficit) & $\begin{array}{l}\text { Current } \\
\text { Asset }\end{array}$ & $\begin{array}{l}\text { Current } \\
\text { Liability }\end{array}$ & $\begin{array}{l}\text { Current Nett } \\
\text { Asset/(Liability) }\end{array}$ \\
\hline 2017 & 0.38 & 0.21 & 0.17 & 1.91 & 0.06 & 1.85 \\
\hline 2016 & 0.33 & 0.17 & 0.16 & 1.72 & 0.05 & 1.67 \\
\hline 2015 & 0.22 & 0.21 & 0.01 & 1.53 & 0.05 & 1.48 \\
\hline 2014 & 0.37 & 0.23 & 0.14 & 1.64 & 0.06 & 1.58 \\
\hline 2013 & 0.21 & 0.17 & 0.04 & 1.51 & 0.07 & 1.44 \\
\hline 2012 & 0.21 & -0.13 & 0.08 & 1.45 & 0.06 & 1.39 \\
\hline 2011 & N.A. & N.A. & N.A. & N.A. & N.A. & N.A. \\
\hline 2010 & 0.21 & 0.09 & 0.12 & 1.22 & 0.55 & 1.17 \\
\hline 2009 & 0.21 & 0.10 & 0.11 & 1.09 & 0.05 & 1.04 \\
\hline
\end{tabular}

98 Legal Notification No. 293 dated $3^{\text {rd }}$ September 1959. The affected section is S.2 (i), The Sultan Idris Religious and Charitable Trust Enactment 1917 (Pk. 3 of 1917). 


\begin{tabular}{|l|l|l|l|l|l|l|}
\hline Year & \multicolumn{3}{|c|}{$\begin{array}{l}\text { Comprehensive Income Statement Ended } \\
\mathbf{3 1}^{\text {t }} \text { December Every Year (MYR mil) }\end{array}$} & \multicolumn{3}{|l|}{$\begin{array}{l}\text { Financial Statement Ended in 31 } \\
\text { Every Year (MYR mil) }\end{array}$} \\
\cline { 2 - 7 } & Income & Expense & Surplus/(Deficit) & $\begin{array}{l}\text { Current } \\
\text { Asset }\end{array}$ & $\begin{array}{l}\text { Current } \\
\text { Liability }\end{array}$ & $\begin{array}{l}\text { Current Nett } \\
\text { Asset/(Liability) }\end{array}$ \\
\hline 2008 & 0.20 & 0.09 & 0.11 & 0.96 & 0.05 & 0.91 \\
\hline 2007 & 0.2 & 0.07 & 0.13 & 0.85 & 0.05 & 0.8 \\
\hline 2006 & 0.22 & 0.08 & 0.14 & 0.71 & 0.05 & 0.66 \\
\hline 2005 & 0.20 & 0.09 & 0.11 & 0.58 & 0.06 & 0.52 \\
\hline 2004 & 0.20 & 0.10 & 0.10 & 0.47 & 0.06 & 0.41 \\
\hline 2003 & 0.20 & 0.09 & 0.11 & 0.36 & 0.05 & 0.31 \\
\hline 2002 & 0.19 & 0.11 & 0.08 & 0.24 & 0.04 & 0.20 \\
\hline
\end{tabular}

Source: Auditor-General Report 2003-2017.

The above chart clearly shows that the trust's financial condition is in good shape. For example, income had increased from MYR 0.19 million (USD45, 934.75) in 2002 to MYR 0.38 million (USD91, $865.15)$ in 2017. Similarly, the trust had increased its surplus from MYR 0.08 million (USD19, 340.03) in 2002 to MYR 0.17 million (USD 41, 097.57) in 2017. Although the trust has also increased its current asset and liability, the current net asset still exceeds its liability which stands at MYR 1.85 million (USD 447,238.24) worth of assets.

\section{HISTORICAL ANALYSIS}

\section{i. Legacy of Sultan Idris Mersid Azam Shah}

Sultan Idris Mersid Azam Shah ibni Almarhum Raja Bendahara Alang Iskandar was born on $19^{\text {th }}$ June 1849 in Kuala Keboi, Kampar, Perak, and died on $14^{\text {th }}$ January 1916 at the age of $67 .{ }^{100} \mathrm{He}$ was the $28^{\text {th }}$ Sultan who ruled Perak for twenty-nine years from 1887 to 1916 . As the third prince of Raja Bendahara Alang Iskandar and Che' Ken Uda Sari Binti Abdul Rahman, he had four siblings; a half-sister, ${ }^{101}$ one-half brother, ${ }^{102}$ and two full brothers. ${ }^{103}$

100 Hussain Mahmud., "Sultan Idris: satu kajian peribadi," Malay Civilisation, accessed on $24^{\text {th }}$ April, 2021, http://www.malaycivilization.com.my/items/show/133652.

101 Raja Teh Mas.

102 Raja Hasan.

103 Raja Kulop Muhamad and Raja Lope Ahmad. 
He married seven wives ${ }^{104}$ at different times and had twelve children from four wives. ${ }^{105}$ However, upon his death, only two wives were mentioned in the Sultan Idris Estate Enactment 1917 (Pk. 2 of 1917), namely, Raja Perampuan Aishah binti Almerhum Sultan Yusuf and Raja Permeisuri Uteh Mariah binti Haji Sleman. ${ }^{106}$

His study includes religious education (reading al-Quran, reading and writing Jawi script) through home-schooling at his father's residence at Kuala Keboi as there was no formal modern school at that time. The oldest school in Perak at that time was the Anglo-Chinese School which was founded in 1895 in Ipoh, Perak. ${ }^{107}$ However, during that year, Sultan Idris had already reigned as the Ruler of the State. This religious background had contributed to his commitment towards waqf development in his state.

During Sultan Idris's reign, he played a prominent role in creating the Federated Malay States in 1895. He led the first 'Durbar' of the Malay Rulers' meeting in Kuala Kangsar on $14^{\text {th }}$ and $15^{\text {th }}$ July 1897. He also contributed to the establishment of the Malay College (1905), the King Edward VII School, Taiping (1906), and the Malay Teachers College, Matang. ${ }^{108}$

104 Raja Nuteh Aishah binti Al-Marhum Sultan Yusof Sharifuddin Mudzaffar Shah, Che' Uteh Mariah binti Haji Sulaiman, Sharifah Alawiyah, Sharifah Maheran, Che' Long Polam, Che' Ngah Manah and Che' Suyah.

105 Raja Abdul Jalil (from Raja Nuteh Aishah binti Al-Marhum Sultan Yusof Sharifuddin Mudzaffar Shah), Raja Harun ar-Rashid, Raja Abdul Rashid, Raja Haji Shu'ib, Raja Shaharuddin, Raja Puteh Kalsom, Raja Badariah, Raja Halijah (from Uteh Mariah), Raja Abdul Hamid, Raja Ngah Halimah and Raja Alang Iskandar (from Che' Ngah Manah) and Raja Puteh Mahiyah (from Che' Long Polam). Rest of wives (Sharifah Alawiyah, Sharifah Maheran and Che' Suyah) did not bore any child. The Sultan Idris Estate (Pk.2 of 1917), Second Schedule.

107 Amanda Yeap, "Alumni aims to make oldest English school in Perak a top choice", The Star< https://www.thestar.com.my/metro/community/2015/07/28/towardsgreater-heights-alumni-aims-to-make-oldest-english-school-in-perak-atop-choice $>$ (accessed on $20^{\text {th }}$ September 2021.

108 Nor Adina Abdul Kadir, Mohd Farhan Abd Rahman, and Mohamad Shafiei Ayub, "The Relationship between the Ulama and Malay Intellectuals in the Development of Islamic Education in Perak, 19221999," International Journal of Academic Research in Business and 


\section{ii. Profile of Properties Acquisition by Sultan Idris and Its Contribution to Waqf}

It was reported that Sultan Idris owned thirty-three (33) lots of shophouses in Kuala Kangsar in the early century. ${ }^{109}$ In total, the Sultan and this family acquired 127 lots of shophouses with the active period of 1905. After he died in 1916, all the shop lots changed hands except for the sixteen shops entrusted to Sultan Idris Religious and Charitable Trust. ${ }^{110}$ The rest of the shop lots were transferred to four trustees: a British, two Malay high officials, and a British official. The lots were then transferred to Chinese and other communities from 1917 to 1920. ${ }^{111}$

Although the reports did not mention about waqf of the Sultan, the dedication of properties under the charity's name was common, especially during the British influence. Administratively and legally, due to the lack of a specific religious entity looking after waqf at that time, most of the waqf properties were registered as trust properties.

Tsukasa Mizushima suggested that the acquisition of shop lots of the Sultan, his family members, and other Malay officials at the beginning of the century was possibly due to the rubber industry's boom in the Kuala Kangsar area. ${ }^{112}$ His Royal Highness was reported as one of the native gentlemen who planted no less than 15,000 acres of rubber in 1898 after selling his coffee estate in Kuala Kangsar to the Perak Government for $\$ 8,500 .{ }^{113}$ Secondly, it was reported that in 1905 , the rubber boom became 'the dominant topic conversation' and 'the rubber-culture has come to stay, for the art of tapping appeals to the Malays.' This economic activity was fortified with the increased acreage of land planted with rubber, amounting to 45,000 acres and

Social Sciences 10, no. 4 (2020): 497 https://doi.org/10.6007/ijarbss/v10i4/7151.

109 Tsukasa Mizushima, “A Historical Study on Land Transaction in a Local Town in Malaysia - Kuala Kangsar Shop Lots between 1885 and 1995," Regional Views, no. 10 (1997); 87-111.

110 Ibid, 97.

111 Ibid, 96.

112 Ibid, 88.

113 Gullick, J.M., Rulers and Residents Influence and Power in the Malay States 1870-1920 (Singapore; Oxford University Press, 1992); 213. 
20,432 coolies employed in 1907. It was reported that Perak's revenue in 1875 was $\$ 226,000$, which had increased to $\$ 11,332,272$ in $1904 .{ }^{114}$

By 1912, four-fifths of the Malay agriculturists were planting rubber. This trend emerged after the first nine rubber tree was planted in Kuala Kangsar in 1877 by Henry Nicholas Ridley. In 1897, around 35,000 rubber seeds were supplied to planters by the government garden at Kuala Kangsar. ${ }^{115}$ Sultan Idris, as the most educated and knowledgeable Malay, noticed the importance of these business opportunities. Later similar to his contemporary, the millionaire, Loke Yew, who opined that bricks and mortar business is a better investment than rubber, His Royal Highness purchased shophouses in Kuala Kangsar 1905 and was considered as the principal purchaser. ${ }^{116}$

Another possible factor leading to the active acquisition of properties was the growth of mining activity in Perak. This activity was seen through the list of property endowed by Sultan Idris to his family members, consisting of seventy-four mining lands in Kuala Kangsar, Kinta, and Batang Padang districts. ${ }^{117}$ At the beginning of the century, Perak's total population was 361,345 consisting of 179,345 Chinese, 145,000 Malays, 35,000 Indians, and 2,000 Europeans and Eurasians. ${ }^{118}$ From this figure, many were single migrants working in the tin mines and other fields. ${ }^{119}$

The third possible revenue for Sultan Idris was his annual royal payment (chabut) on his mining lands worth more than $\$ 83,000$, annual income from his town and rented properties amounted to $\$ 42,000$, and political allowance from the state government worth $\$ 52,000 .{ }^{120}$ From these incomes, upon his intestate death, his estate created two types of waqf, namely the religious and family waqf.

114 C.P. Lucas, A Historical Geography of the British Colonies (Oxford; Clarendon Press, 1906); 217, 223.

115 Tsukasa, 88.

116 Gullick, 213.

117 The Sultan Idris Estate Enactment 1917 (Pk. 2 of 1917), First Schedule.

118 Tsukasa, 88.

119 Tsukasa, 88.

120 Gullick, 213. 


\section{SUSTAINABILITY FACTORS}

From the above discussion, several pertinent factors leading to the sustainability of this Royal waqf could be deduced. The factors are as follow:

\section{(i) The waqfs were established through a written legal instrument}

This situation could be seen from the above discussion where Sultan Idris's estate established two enactments after the death of Sultan Idris in 1916. The enactments were the Sultan Idris Estate Enactment 1917 Cap 208 (Pk. 2 of 1917) and Sultan Idris Religious and Charitable Trust Enactment 1917 Cap. 209 (Pk. 3 of 1917). These two enactments underlined some strict guidelines. For example, the Sultan Idris Religious and Charitable Trust Enactment 1917 Cap. 209 (Pk. 3 of 1917) mentioned that (i) the properties could not be sell, transfer, mortgage, charge, or otherwise encumber any part of the lands except with written assent from written assent, from both the Ruler of the State and the Resident; ${ }^{121}$ (ii) the trustees shall administer and manage the properties to the best advantage; ${ }^{122}$ (iii) money controlled by the Trustees shall not be disbursed except under written authority; ${ }^{123}$ and (iv) the trustees must keep accurate accounts of the income and profits. ${ }^{124}$ These guidelines proved to be effective for the longevity of these waqfs.

(ii) The waqf by Sultan Idris was made based on the English law of trust, but the spirit and principles of the waqf to permanently benefit the beneficiaries remain intact;

There are several similarities between the two trusts and waqf from four perspectives, namely, (1) the sighah (declaration), i.e. by the proclamation of both enactments; (2) waqif (founder), i.e. Sultan Idris, (3) the mawquf 'alaih (beneficiary), i.e. Sultan's wives, children and Muslim at large, and (4) mawquf (endowed property), i.e. the

121 Sultan Idris Religious and Charitable Trust 1917 (Pk. 3 of 1917) s 5. 
shophouses, rubber estates, and tin mines. As for the trustee appointment, it is also similar to the concept of nazir under Islamic law. As such, it can be safely assumed that both Sultan Idris's trust was waqf in spirit.

(iii) The appointment of the Sultan's family member as the trustees alongside a committee proved to be crucial for the sustainability of the waqf;

Another point that can be deduced from Sultan Idris's waqfs is the appointment of his family member as trustees. This step is crucial as the Sultan's descendant would be a member of the trustee meeting and consequently aware of the waqf's development. It is similar to family waqf under Islamic law, where the appointed nazir is from the waqif's family. This practice is different from the current practice where waqif is not a member of council meetings. As such, many waqifs are not aware of the development of their waqf.

\section{(iv) The existence of check and balance process through legal provisions}

Section 12(ii) of the Sultan Idris Religious and Charitable Trust 1917 (Pk. 3 of 1917) outlined the statutory duty of auditing the waqf accounts once a year. ${ }^{125} \mathrm{~A}$ check on this duty has shown that at present, the duty is being done carefully by the National Audit Department, as mentioned in Table 1. However, there is no such requirement for the family waqf, i.e. The Sultan Idris Estate 1917 (Pk.2 of 1917). Nevertheless, during the time of the British, the trustees were required to exhibit the accounts twice a year at the office of the Secretary to Resident. ${ }^{126}$ Furthermore, the trustees were also responsible for

125 Sultan Idris Religious and Charitable Trust 1917 (Pk. 3 of 1917), s 12 (ii) reads, "The said accounts shall be audited once a year by a person to be appointed in that behalf by the Resident, and the cost thereof, if any, may be defrayed from the moneys controlled by the Trustees under the provisions of this Enactment."

126 The Sultan Idris Estate 1917 (Pk. 2 of 1917), s 14(i) reads, "The Trustee shall keep clear and accurate accounts of the trust-property and shall in the months of January and July in every year exhibit in the office of the Secretary to Resident at Taiping an account of the said property made up 
furnishing the accurate information of properties at any time requested by the Resident. ${ }^{127}$ These guidelines showed that there was a check and balance process towards the waqfs.

\section{CONCLUSION}

This writing shows that the waqf establishment within written legal instruments proved to be everlasting. Secondly, the royal waqf by Sultan Idris was created based on the English law of trust, but the waqf's spirit and principles were upheld in almost all the charitable acts which contribute to the beneficiaries. Thirdly, the appointment of the Sultan's descendant as the trustee alongside a committee proved crucial to the waqf's sustainability. Fourthly, the existence of a check and balance process through provisions is necessary. These practices have not been followed under the current waqf practices where the waqif's descendant is no longer part of the waqf stakeholders under the State Islamic Religious Council unless explicit approval is given from the Majlis or the Sultan. This writing has highlighted the important roles of the Sultan or the royal family towards the developing waqf in Perak. While the British had construed waqf as a trust and enacted specific laws to administer it, they also influenced the court's decision in resolving disputes on waqf or charitable trust, including family trust. Nevertheless, it was through the enactment of the law that Sultan Idris's waqf has been secured and remains perpetual.

to the last day of the preceding month and showing the assets which have come into his hands and the manner in which the same have been applied or disposed of."

127 The Sultan Idris Estate 1917 (Pk. 2 of 1917), s 14(ii). 